\title{
Tratamento da obesidade: modelo de grupo baseado em terapia cognitivo-comportamental
}

Guimarães JB, Tavares M, Neumann CR

Serviço de Atenção Primária à Saúde - Hospital de Clínicas de Porto Alegre. Departamento de Medicina Social da Faculdade de Medicina da Universidade Federal do Rio Grande do Sul

Introdução: 0 tratamento da obesidade em grupos (GO) tem um resultado variável conforme a metodologia utilizada, chegando a se obter uma perda ponderal (PP) de até $10 \%$ em três a seis meses. Embora muito utilizada na atenção primária, esta abordagem tem sido pouco estudada. Objetivo: Avaliar a evolução dos pacientes em acompanhamento em um GO, correlacionando seu perfil com sua permanência no grupo e a PP obtida. Também se buscou comparar os resultados com a literatura. Materiais e Métodos: Estudo não-controlado, quase-experimento, com intervenção. Foram avaliados os pacientes que frequentaram pelo menos uma reunião do GO na Unidade Básica de Saúde HCPA, no período de outubro de 2007 a outubro de 2008. A busca ao GO foi por demanda espontânea ou por indicação do médico na consulta. Em encontros semanais, com duração de 90 minutos, foram utilizadas técnicas de educação cooperativa, cognitivo-comportamentais e motivacionais para PP, adesão à dieta e atividade física, aferido peso semanalmente, discutidos os resultados em grupo e fornecida dieta hipocalórica. Os pacientes foram classificados em: não-aderentes (NA) e aderentes (A), conforme tenham participado de $\leq 2$ ou $\geq 3$ encontros, respectivamente. Foram avaliados a PP e os possíveis fatores relacionados a isso. Os resultados são descritivos e em comparações, utilizando o teste $t$, Mann Whitney, qui-quadrado e a correlação de Spearmann. 0 nível de significância foi de 5\%. Resultados: Foram avaliados 69 pacientes, $62(89,9 \%)$ do sexo feminino, idade de 49,2 $\pm 13,2 ; 33$ classificados como NA e 36 como A. Comparando estes dois grupos, observamos a diferença quanto ao peso inicial: $N A=98,7 \pm 24,7$ e $A=88,4 \pm 16,8$, $p<0,05$; e quanto ao percentual de mulheres: $N A=26$ $(81,3 \%)$ e $A=35 \quad(97,2 \%), \quad p<0,05$; e semelhança quanto à idade, escolaridade, cor e estado civil. Houve correlação entre o número de reuniões e a PP $(r=(-) 0,61$, $p<0,0001)$. Nos 20 participantes com permanência $\geq 12$ semanas, observou-se PP média de 6,63 kg. Conclusões: 0 GO obteve um bom resultado para os pacientes mais aderentes e parece ser mais adequado ao tratamento das mulheres e indivíduos com menores graus de obesidade. 0 ideal será a inclusão de um Grupo Controle em um próximo estudo.

\section{Obesity treatment: group model based on cognitive behavioral therapy}

\section{Guimarães JB, Tavares M, Neumann CR}

Primary Attention Service - Hopsital de Clínicas of Porto Alegre

Department of Social Medicine of Medical School of the Federal University of Rio Grande do Sul

Introduction: The obesity treatment in groups (OT) has a variable result depending on the methodology used, having a weight loss (WL) of up to 10\% in 3-6 months. Although it is very used in the primary attention, this method has been little studied. Objective: To evaluate the evolution of the patients with accompaniment in a OT, relating their profile to their stay in the group and the WL obtained. We also compared the results with literature. Materials and Methods: Non-controled study, almost experiment, with intervention. The evaluated patients have been to, at least, one OT meeting in the Basic Health Unit HCPA in the period of October 2007 to October 2008. The search for OT was by spontaneous demand or suggestion of the doctor at the consult. During weekly meetings, with duration of 90 minutes, cooperative education, cognitive behavior and motiviational techniques for WL were used, the start of diet and physical activity, weekly weight checks, results discussed in the group and a hipocaloric diet was provided. The patients were classified in: nonadherent (NA) and adherent (A), according to participation in $\leq 2$ or $\geq 3$ meetings, respectively. The PP and possible factors related to this were evaluated. The results are descriptive and comparative using the t-Test, Mann Whitney, chi-square tests and the Spearman correlation. The level of significance was $5 \%$. Results: Sixty-nine patients were evaluated, 62 (89.9\%) were female, age of $49.2 \pm 13.2$; 33 were classified as NA and 36 as $\mathrm{A}$. Comparing these two groups, we observed the diference regarding initial weight: $N A=98.7 \pm 24.7$ and $A=88.4 \pm 16.8, p<0.05$; and as for the percentage of women: $\mathrm{NA}=26(81.3 \%)$ and $\mathrm{A}=35(97.2 \%), \mathrm{p}<0.05$; and similarity of age, level of education, color and marital status. There was a correlation between the number of meetings and the WL $(r=(-) 0.61, p<0.0001)$. In the 20 participants that stayed $\geq 12$ weeks, we observed an average of $6.63 \mathrm{~kg}$. Conclusions: The OT had a good result for the patients who were more adherent and seems to be more adequate for the treatment of women and individuals with lower obesity level. The ideal would be the addition of a control group in a next study.
Tratamiento de la obesidad: modelo del grupo basado en terapías cognitivo comportamental

Guimarães JB, Tavares M, Neumann CR

Servicio de Atención Primaria a la Salud - Hospital de Clínicas de Porto Alegre

Departamento de Medicina Social - Facultad de Medicina - Universidad Federal del Rio Grande do Sul

Introducción: El tratamiento de la obesidad en grupos (GO) tiene un resultado variable conforme la metodología utilizada, llegando a ser obtener una pérdida ponderal(PP) hasta 10\% en 3-6 meses. Aunque mucho utilizada en atención primaria, esta abordaje ha sido un poco estudiada. Objetivo: Evaluar la evolución de los pacientes en seguimiento en un GO, correlacionando su perfil con su permanencia en grupo y la PO obtenida. También se busca comparar los resultados con la literatura. Materiales y Métodos: Estudio no controlado, casi experimento, con intervenciones. Se evaluaron los pacientes que frecuentaron por lo menos una reunión del G0 en Unidad Básica de Salud HCPA en período de octubre de 2007 a octubre de 2008.La búsqueda al G0 ha sido por demanda espontánea o por indicación del médico en consulta. En encuentros semanales, con duración de 90 minutos, se utilizaron técnicas de educación cognitivo comporta mentales y motivacionales para PP ,adhesión a la dieta y actividades físicas, evaluado peso semanalmente, discutidos los resultados en grupo y fornecida dieta hipocalórica. Los pacientes se clasificaron e: no adherentes(NA) y adherentes (A) conforme tengan participado de $\leq 2$ ou $\geq 3$ encuentros, respectivamente y en comparaciones utilizando TesteT,Mann Whitney, Chi- cuadrado y correlación de Spearmann. Nivel de significancia de 5\%. Resultados: Se evaluaron 69 pacientes, $62(89,9)$ del sexo femenino, edad $42,2 \pm 13,2$; 33 clasificados como NA y 36 como A. Comparando estos dos grupos, observamos la distinción cuanto al peso inicial: $N A=98,7 \pm 24,7$ e $A=88,4 \pm 16,8, p<$ 0,$05 ; y$ cuanto al porcentaje de mujeres: $\mathrm{NA}=26(81,3 \%)$ e $A=35(97,2 \%), p<0,05 ; y$ similitud cuanto a la edad, escolaridad, color y estado civil. Hubo correlación entre el número de reuniones y la $\mathrm{PP}(\mathrm{r}=(-) 0,61, \mathrm{p}<0,0001)$. Nos 20 participantes con permanencia $\geq 12$ semanas se observó PP media de 6,63 Kg. Conclusiones: El GO obtuvo un buen resultado para los pacientes más adherentes y parece ser más adecuado al tratamiento de las mujeres y individuales con menores grados de obesidad. Lo ideal será la inclusión de un grupo controle en un próximo estudio 